\title{
Tema: Educação profissional e tecnológica
}

\author{
Remi Castioni \\ Universidade de Brasília
}

\section{Apresentação}

O presente número da revista Linhas Críticas inaugura uma discussão sobre tendências da educação profissional no Brasil e no Mundo. Passada uma década da decisão do Estado brasileiro de expandir a oferta de educação profissional, oportunizada pela Lei $n^{\circ} 11.195$, de 18 de novembro de 2005 , que revogou a até então proibição da ampliação da rede federal (Lei $n^{\circ} 8.948$, de oito de dezembro de 1994).

Com a transformação dos Centros Federais de Educação Tecnológica (CEFETs) nos Institutos Federais de Educação, Ciência e Tecnologia (Institutos Federais), a partir da Lei $n^{\circ} 11.892$, de 29 de dezembro de 2008, e depois, com a Lei $n^{\circ} 12.513$, de 26 de outubro de 2011, que criou o Programa Nacional de Acesso ao Ensino Técnico e Emprego (Pronatec), o governo federal pretendeu patrocinar outras iniciativas de formação profissional, tanto integradas ao ensino médio, como também, atrair outros públicos para a formação profissional, como os beneficiários do Bolsa Família e do Programa do Seguro Desemprego. Além disso, tratou também, a partir do Pronatec, de incorporar ao sistema federal de ensino os serviços nacionais de aprendizagem, criados na década de 1940. Esse movimento criou condições objetivas para a ampliação da oferta de educação profissional à população brasileira. Somente a Rede Federal passou de 140 para 644 unidades em mais de 500 municípios brasileiros.

Essas mudanças impulsionaram a inscrição de metas audaciosas para a educação profissional no Plano Nacional de Educação (Lei no 13.005, de 25 de junho de 2014), que dificilmente serão cumpridas, uma vez que foram fixadas em um momento de alta performance da expansão federal.

Com a crise do Estado brasileiro e a interrupção do mandato da presidenta da República, Dilma Vana Rousseff, cuja campanha eleitoral tinha o Pronatec num lugar de destaque, percebe-se, no presente momento, refluxo na expansãodo setor, marcada por novas orientações governamentais na educação. No caso específico do ensino médio e sua perspectiva de integração com a educação profissional, uma nova Lei ( $n^{\circ} 13.415$, de 16 de fevereiro de 2017 ) propõe-se a novos formatos e uma nova organização da educação profissional. 
Com esse objetivo, os presentes textos, ao mesmo tempo que dialogam com o processo de expansão da educação profissional no Brasil, apresentam algumas reflexões acerca de como alguns países enfrentaram a oferta de educação profissional para sua população em momentos de crise. No processo de expansão da Rede Federal, ficou ausente um diálogo com experiências exitosas de outros países, que poderia ter evitado problemas na implementação dessa importante política pública.

O primeiro artigo internacional, de Oscar Valiente e Adrian Zancajo, intitulado, La formación profesional en España: efectos sobre la empleabilidad en tiempos de crisis, analisa, sob a ótica da economia espanhola, como a elevação das taxas de desemprego, a partir da crise de 2008 , proporcionaram aumento na opção dos jovens pela educação profissional e como esta contribuiu para o crescimento da empregabilidade dessa faixa etária. Além disso, mostra como as empresas espanholas tentaram se aproximar dos modelos de formação profissional mais exitosos do mundo, como do modelo dual alemão.

O texto de Janis Vossiek, Conflito e cooperação: reformas da formação profissional no Reino Unido, na Irlanda e na Austrália durante as crises econômicas, situa sua análise nestes três estudos de caso a partir da caracterização das variedades de capitalismo e demonstra que o aspecto institucional é um fator importante e que impulsiona as reformas da aprendizagem profissional. Na sua abordagem, situa o papel que governos progressistas que promoveram abordagens cooperativas, reunindo sindicatos e empregadores nas reformas da aprendizagem, lograram mais sucesso do que o governo neoliberal de Tatcher, que reduziu a influência dos sindicatos e impulsionou a mercantilização da oferta de formação profissional.

Ao analisar o caso brasileiro, a partir da fixação da meta 11, pelo Plano Nacional de Educação, os autores Camila Porto Fasolo e Remi Castioni demonstram no texto Educação profissional no PNE 2014-2024: contexto de aprovação e monitoramento da meta 11 que houve a fixação de parâmetros muito ousados durante a tramitação do PNE no Congresso Nacional, em boa medida, influenciados pelo até então entusiasmado desempenho de oferta de vagas a cargo do Pronatec.

O texto de Caetana Juracy Rezende Silva e Olgamir Francisco de Carvalho, denominado Aspectos epistemológicos e pedagógicos da educação profissional e tecnológica: implicações para a prática docente apresenta, no quadro de expansão da educação profissional proporcionada pelos Institutos Federais, que a contratação de quase 20 mil professores durante o processo de crescimento da Rede Federal descuidou do principal ingrediente para a efetivação dessa oferta: a formação docente.

A resenha elaborada por Denise Bianca Maduro Silva a partir do livro Evasão na 
educação: estudos, políticas e propostas de enfrentamento aborda a temática da evasão na educação profissional, que pouco tem sido estudada. As pesquisas realizadas pela Rede Ibero-Americana de Estudos sobre Educação Profissional e Evasão Escolar (RIMEPES) foram pioneiras no estudo do abandono escolar na educação profissional e mostram a necessidade de serem pensados mecanismos para manteresses alunos no fluxo regular. 